UDC 546.296: $316.654(470)$

DOI: 10.21668/health.risk/2021.3.03.eng

Research article

\title{
RADON RISK COMMUNICATION ISSUES: RESULTS OF THE ALL-RUSSIAN PUBLIC OPINION SURVEY
}

\section{A.A. Davydov, A.M. Biblin, D.V. Kononenko}

St. Petersburg Research Institute of Radiation Hygiene after Professor P.V. Ramzaev, 8 Mira Str., St. Petersburg, 197101, Russian Federation

1,500 respondents took part in an Internet survey conducted in autumn 2020 in the Russian Federation. The survey was a part of the Radon Cross-Cultural Multilingual Public Opinion Survey (STEAM project) in the framework of the IAEA technical cooperation project RER9153. The survey was representative for the population of the country as per sex, age, and a region of residence. Random sampling error didn't exceed $2.5 \%$ for $95 \%$ confidence interval. All respondents were given some information on radon that was as similar as possible in questionnaires published in languages spoken in all 22 countries that took part in the STEAM project; it was done in order to provide an opportunity to make further cross-country comparison of the survey results. The objective of the survey was to investigate what attitudes people had towards their health and towards radon as a possible health risk factor.

The survey revealed that in the Russian Federation people were rather poorly aware about radon. Only $31.7 \%$ respondents stated that they were to a greater or lesser extent informed about radon. The level of knowledge about radon as a health risk factor was at a comparable level. For the majority of respondents, information about radon received from Rospotrebnadzor and its subordinate research institute formed the perception of radon as a risk factor that requires actions to mitigate its impact on health. Medical specialists turned out to be the most trustworthy source of information about health risks, first of all, family doctors and physicians in polyclinics; people also trusted medical prevention centers, Rospotrebnadzor, regional and local public health care authorities.

Results of the presented survey that was the first social survey focusing on the radon problem and conducted throughout the country can be used as a basis for planning communication strategies within the framework of both national and regional radon programs.

Key words: radon, natural exposure, risk communication, radiation risk, radiation protection, social survey, risk awareness, National radon program, risk perception.

Radon is a natural radioactive gas, colorless, tasteless, and odorless. It is not only the most significant natural source of public exposure worldwide [1-3], but also a major contributor to the individual annual radiation dose due to all sources of ionizing radiation (accounting for more than $50 \%$ of the total dose to the population of the Russian Federation [4-6]). At the same time, radon often remains in the "information shadow" of other sources, primarily nuclear power facilities and various medical equipment, which actually make a much smaller contribution to the collective dose. It is a proven fact that radon and its progeny are the second leading cause of lung cancer after tobacco smoking for smokers and the main one for non-smokers $[7,8]$.

International organizations, such as the International Atomic Energy Agency (IAEA), the World Health Organization (WHO), the International Commission on Radiological Protection (ICRP), emphasize the importance of developing national radon programs (or radon action plans), conducting national and re-

(C) Davydov A.A., Biblin A.M., Kononenko D.V., 2021

Artem A. Davydov - Junior researcher at Information and Analytical Center (e-mail: a.davidov@niirg.ru; tel.: +7 (981) 762-94-97; ORCID: http://orcid.org/0000-0002-5390-4332).

Artem M. Biblin - Senior researcher, the Head of Information and Analytical Center (e-mail: a.biblin@niirg.ru; tel.: +7 (981) 958-43-09; ORCID: http://orcid.org/0000-0002-3139-2479).

Dmitry V. Kononenko - Researcher at the Laboratory for dosimetry of natural sources of radiation (e-mail: d.kononenko@niirg.ru; tel.: +7 (911) 908-28-02; ORCID: http://orcid.org/0000-0002-1392-1226). 
gional radon surveys in dwellings, public buildings with high occupancy factors, and workplaces, assessment of health risks due to radon, establishment of reference levels for indoor radon concentration and standards for the activity concentration of natural radionuclides in building materials [1-3].

The strategy of communication with stakeholders, including the population, is supposed to be an integral part of national radon programs. The problem of low public awareness of radon and the health risk it poses is still typical for many countries [9-16], including the Russian Federation. This leads to the fact that there is no market for radon protection and remediation of buildings in our country yet [17].

Conducting any information campaigns on radiation safety issues requires preliminary social research due to the complexity of these issues, the presence of persistent myths about radiation and the possibility of increasing radiophobia among the population [18].

It should be noted that some critics claim that public opinion polls put a person in a model situation and are aimed at finding out something that a particular individual may not have, namely, opinion on a specific issue $[19,20]$. It turns out that polls in that way do not reflect public opinion, but rather form it themselves [21]. This paradox can also manifest itself in the case of such a little-known issue for the population as radon because it is relevant for the radiation safety experts and, to some extent, public health care authorities, but not for the general population, since it rarely appears in the focus of the media. In case there is low public awareness of some issue, it is reasonable to use the survey methodology with the enrichment of public opinion, i.e. providing information on the issue with subsequent investigation of the reaction to it.

This methodology was chosen for the international radon cross-cultural multilingual public opinion survey "STEAM project", coordinated by the Institute of Public Health (Bucharest, Romania). The survey was initiated within the framework of the IAEA Technical Cooperation Project RER9153 "Enhancing the Regional Capacity to Control Long
Term Risks to the Public due to Radon in Dwellings and Workplaces". St. Petersburg Research Institute of Radiation Hygiene after Professor P.V. Ramzaev conducted this survey in the Russian Federation.

It should be noted that any change of a person's protective behavior related to health, from complete ignorance that protective behavior is possible to specific active actions (ordering measurements of indoor radon concentration, remediation in houses after initial measurements if necessary), goes through several stages:

1) Ignorance of protective behavior;

2) Awareness, but not engagement;

3) Engagement and decision-making on specific actions;

4) Making a decision not to take protective actions (termination of the ascending sequence to protective behavior);

5) Making a decision to take specific actions, but not taking them in fact;

6) Action (one-time, periodic);

7) Consolidation of a new protective practice in the field of health $[22,23]$.

At different stages, various risk communication strategies are effective, stimulating the population to move to the next stage. The present survey was focused on respondents who were in the first stages, with a cross-sectional type of research being best suited for them, as opposed to a longitudinal one used in case of transition from the stage of ignorance to the stage of decision-making on specific actions, when one group of respondents is interviewed several times over a certain period of time.

The purpose and objectives of the survey were set in accordance with the type of survey and the supposed low public awareness of radon and its health impact.

The purpose was to study the attitudes of Russians towards their health and radon as a risk factor for health.

\section{Objectives:}

- study the attitude of the population towards their health;

- measure the level of public awareness of radon;

- inform respondents of radon; 
- determine a degree to which information on radon was assimilated by respondents and identify possible failures in risk communication;

- assess respondents' readiness to measure indoor radon concentration in their homes and take protective actions if necessary;

- identify the sources of information on health risk factors, including radon, that are most used by respondents and deserve their trust.

Materials and methods. An online survey was conducted with 1,500 respondents in the fall of 2020 . The questionnaire was preliminarily translated from English into Russian and adapted. In addition, we carried out a pilot study to refine the wording of the questions. The survey was representative for the population of the country as per sex, age, and a region of residence. Random sampling error didn't exceed $2.5 \%$ for $95 \%$ confidence interval. Participation in the survey was voluntary. Quotas for the survey were calculated on the basis of the Federal State Statistics Service data ${ }^{1}$. At the beginning, a link to the online questionnaire was distributed in popular social media in Russia (Vkontakte, Odnoklassniki, Facebook), and then respondents were additionally selected with the help of service Anketolog.ru, which was the platform for the online survey.

Microsoft Excel was used to accumulate, correct, and systematize initial results and to visualize the results of the analysis. IBM SPSS was used to analyze initial results of the survey with parametric and nonparametric statistical methods. Nominal variables were described with absolute values and percentages.

The nominal data were compared using Pearson's $\chi^{2}$ test to assess the significance of differences between the actual number of outcomes or qualitative characteristics of the sample falling into each category and the theoretical number that could be expected in the groups under study if the null hypothesis was true.
First, we calculated the expected number of observations in each cell of the contingency table under the condition that the null hypothesis of no relationship was true. For this purpose we multiplied the sums of series and columns (marginal totals) and then divided the obtained product by the total number of observations. Then we calculated the value of the $\chi^{2}$ test according to the formula:

$$
\chi^{2}=\sum_{i=1}^{r} \sum_{j=1}^{c} \frac{\left(O_{i j}-E_{i j}\right)^{2}}{E_{i j}},
$$

where $i$ is the number of row (from 1 to $r$ ), $j$ is the number of column (from 1 to $c$ ), $O_{i j}$ is the actual number of observations in cell $i j, E_{i j}$ is the expected number of observations in cell $i j$.

The value of the $\chi^{2}$ test was compared with the critical values for the $(r-1) \cdot(c-1)$ number of degrees of freedom. If the obtained value of $\chi^{2}$ exceeded the critical value, it was concluded that there was a statistical relationship between the risk factor under study and the outcome at an appropriate level of significance.

All respondents were given the following key information on radon that was as similar as possible in questionnaires published in languages spoken in all 22 countries that took part in the STEAM project; it was done in order to provide an opportunity to make further crosscountry comparison of the survey results.

"Radon is a naturally occurring radioactive gas that can be released from soil, rocks and building materials. Radon is colorless, tasteless and odorless. You can find out whether it is present in the air or not only with the help of special devices. Outdoors the concentration of radon is very low because it is rapidly diluted with atmospheric air. However, in closed rooms it can accumulate.

Radon enters the human lungs with inhaled air. There its radioactive radiation can damage cells, which further leads to the increased probability of developing lung cancer. Radon is the second leading cause of lung

\footnotetext{
${ }^{1}$ Federal State Statistics Service. Available at: https://rosstat.gov.ru (20.08.2020).
} 
cancer after smoking. Moreover, the probability of developing lung cancer as a result of exposure to radon in smokers is 25 times higher than in non-smokers. In the Russian Federation, up to 3,000 people die every year from lung cancer caused by radon.

In the Russian Federation, a limit for indoor radon concentration is established and protective measures must be taken if this limit is exceeded. Specialized accredited laboratories in every region can measure radon concentration in your house or apartment and determine whether the limit is exceeded or not. If necessary, specialized project organization will be able to design protective and mitigation measures».

Results and discussion. Most of the respondents $(82.4 \%)$ assessed their health as "satisfactory" and "good". On average, respondents tended to evaluate their health better than the health of other Russian citizens (Table 1). The comparison of these questions made it possible to split the dataset into three parts: those who assessed their health worse than that of others $(5.6 \%)$, those who assessed their health better than that of others $(50.8 \%)$, and those who assessed their health similarly to others (36.3\%). Respondents over 55 years old prevailed among the first group and young people prevailed among the third group.

The majority of the respondents $(70.8 \%)$ claimed to be aware of health risk factors and only $16.1 \%$ noted that they were not aware of them. The distributions of answers to the questions about awareness of risk factors for personal health and for the health of the Russian population were almost equal (Table 2).

According to the results of categorization of respondents' answers to the question "What risk factors, in your opinion, can most strongly affect your health?" with the freedom to choose the answer (without predefined options), the following groups of risk factors were identified: environmental, i.e. related to the state of the environment (air pollution,

Table 1

Respondents' self-assessment of their health and assessment of the health of other Russians, \%

\begin{tabular}{|l|c|c|}
\hline \multirow{2}{*}{ Answer options } & \multicolumn{2}{|c|}{ Questions } \\
\cline { 2 - 3 } & $\begin{array}{c}\text { You would say that your health } \\
\text { in general is }\end{array}$ & $\begin{array}{c}\text { You would say that the health } \\
\text { of Russians in general is }\end{array}$ \\
\hline Poor & 4.4 & 20.8 \\
\hline Satisfactory & 45.3 & 60.4 \\
\hline Good & 37.1 & 9.6 \\
\hline Very good & 6.9 & 0.4 \\
\hline Excellent & 4.5 & 0.3 \\
\hline Don't know & 1.0 & 7.5 \\
\hline I would prefer not to answer & 0.8 & 1.0 \\
\hline
\end{tabular}

Table 2

Respondents' assessment of their awareness of risk factors for themselves and for residents of Russia as a whole, \%

\begin{tabular}{|l|c|c|}
\hline \multirow{2}{*}{\multicolumn{1}{c|}{ Answer options }} & \multicolumn{2}{|c|}{ Questions } \\
\cline { 2 - 3 } & $\begin{array}{c}\text { Regarding the risks factors for your own } \\
\text { health, you would say you are }\end{array}$ & $\begin{array}{c}\text { Regarding the risk factors for the health } \\
\text { of Russians in general, you would say } \\
\text { you are }\end{array}$ \\
\hline Not at all informed & 1.9 & 3.3 \\
\hline Not informed & 14.2 & 16.7 \\
\hline Informed & 48.0 & 51.1 \\
\hline Well informed & 16.9 & 11.3 \\
\hline Very well informed & 5.9 & 3.8 \\
\hline I don't know & 12.6 & 13.1 \\
\hline I would prefer not to answer & 0.6 & 0.6 \\
\hline
\end{tabular}


Respondents' agreement with statements related to their health control, \%

\begin{tabular}{|l|c|c|c|c|}
\hline \multirow{2}{*}{ Answer options } & \multicolumn{4}{|c|}{ Statements } \\
\cline { 2 - 5 } & $\begin{array}{c}\text { I protect myself from } \\
\text { any risk factors that } \\
\text { could affect my } \\
\text { health }\end{array}$ & $\begin{array}{c}\text { I have control over } \\
\text { all risk factors for } \\
\text { my health }\end{array}$ & $\begin{array}{c}\text { The indoor air quality } \\
\text { from my home is } \\
\text { very important for my } \\
\text { health }\end{array}$ & $\begin{array}{c}\text { Decisions about } \\
\text { health risks should } \\
\text { be left to experts }\end{array}$ \\
\hline Strongly disagree & 2.5 & 3.4 & 0.4 & 4.7 \\
\hline Disagree & 16.9 & 27.6 & 1.5 & 22.4 \\
\hline Neither agree nor disagree & 47.1 & 43.8 & 5.7 & 25.0 \\
\hline Agree & 25.6 & 19.3 & 62.7 & 34.8 \\
\hline Strongly agree & 4.4 & 2.7 & 27.6 & 7.8 \\
\hline I don't know & 2.9 & 2.4 & 1.4 & 4.2 \\
\hline I would prefer not to answer & 0.6 & 0.7 & 0.7 & 0.9 \\
\hline
\end{tabular}

Table 4

Respondents' awareness of radon in general and radon as a health risk factor, \%

\begin{tabular}{|l|c|c|}
\hline \multirow{2}{*}{\multicolumn{1}{c|}{ Answer options }} & \multicolumn{2}{|c|}{ Questions } \\
\cline { 2 - 3 } & $\begin{array}{c}\text { How much would you say you know about } \\
\text { radon? }\end{array}$ & $\begin{array}{c}\text { How much do you say you know about the } \\
\text { health risk due to radon exposure? }\end{array}$ \\
\hline Nothing & 38.5 & 43.5 \\
\hline Only a little & 29.4 & 26.7 \\
\hline Something & 23.2 & 20.1 \\
\hline Quite a bit & 6.0 & 6.5 \\
\hline A lot & 2.5 & 2.4 \\
\hline I would prefer not to answer & 0.4 & 0.7 \\
\hline
\end{tabular}

climate change, etc.), bad habits (alcohol, smoking, overeating or improper diet, drugs), various diseases (cardiovascular, including hypertension, heart attacks, diabetes, visual disturbances, etc.), lifestyle (work, sleep disturbances, sedentary lifestyle), stress, COVID-19, poor-quality food and drinking water.

The following population groups can be distinguished based on the respondents' assessment of the control over health risk factors (Table 3):

- People who take their health seriously and agree with the authority of experts $-7.0 \%$;

- People who take their health seriously and disagree with the authority of experts $-8.3 \%$;

- The rest of people who agree with the authority of experts $-35.6 \%$;

- The rest of people who disagree with the authority of experts $-49.1 \%$.

The category "people who take their health seriously" (15.3\%) was calculated as the sum of those who "agree" or "strongly agree" with the first three statements in Table 3 .
The majority of respondents (90.3\%) claimed that air quality was very important to them, $30.0 \%$ claimed that they protected themselves from any risk factors that might affect their health, $22.1 \%$ believed that they controlled all risk factors for their health.

Among those who assessed their health as "good", "very good", or "excellent" (Table 1), the proportion of those who claimed to protect themselves from any health risk factors was higher $(38.7 \%$ vs. $21.8 \%)$, and they were more confident that they controlled all risk factors for their health $(29.5 \%$ vs. $15.1 \%)$. In general, self-assessment of health is positively associated with a serious attitude towards one's health.

The level of knowledge about radon in general turned out to be quite low. Only $23.2 \%$ of respondents heard "something" about it, and another $8.5 \%$ said they knew "quite a bit" or "a lot" about it (Table 4). The level of knowledge about radon as a health risk was at a comparable level, but two points need 
to be noted. Firstly, incompetent individuals in any field tend to overestimate the level of their knowledge (Dunning - Kruger effect) [24]. Secondly, during the online survey, the respondents had the opportunity to get some information on radon before filling out the questionnaire, which could also affect the distribution of answers to the question. Thus, we can reasonably assume that the real awareness is even lower than that presented in the Table 4.

The proportion of those who assessed their knowledge of radon as confident was higher among people whose professional activity was related to ionizing radiation $(15.0 \%$ of respondents answered "quite a lot" and another $15.0 \%$ answered "a lot"). However, awareness of radon remains very low even among this group.

No statistically significant differences in awareness of radon were found between those who were seriously concerned about their health (see Table 3) and those who were not. The relationship between the level of awareness and how respondents assessed their health was also not found. Based on this, we can conclude that information on radon does not reach the audience. It is not available even to people who take serious care of their health.

The first two groups of questions were followed by a part with some key information on radon (see Materials and Methods section) so that the respondents could broaden their knowledge. The next series of statements were offered to assess the perception of the given information (Table 5).

A quarter of respondents $(24.1 \%)$ agreed that measuring radon concentration in their house was a "priority". $13.1 \%$ of respondents had the impression that measuring would be a simple task. A fifth of respondents $(19.3 \%)$ believed that they would have the financial means to take measures to reduce the radon level in their house. Two thirds $(68.8 \%)$ claimed that the decision to take actions to reduce the radon level in the house was not entirely up to them.

Despite the fact that the majority of respondents $(84.2 \%)$ claimed that their homes were always well ventilated, only a third of respondents $(33.4 \%)$ noted that there was no use to measure radon concentration for this reason (Table 6). Hence, we can conclude that ventilation of rooms is perceived by the majority of respondents as insufficient protective measure and the information given to respondents earlier caused them concern. It can be also noted that there were slightly more respondents who cared about ventilation among those who assessed their health positively $(86.5 \%$ vs. $81.7 \%$, calculated as the sum of "agree" and "absolutely agree" answers).

Table 5

Respondents' agreement with statements about reasons preventing them from taking protective measures, $\%$

\begin{tabular}{|l|c|c|c|c|c|}
\hline \multirow{2}{*}{ Answer options } & \multicolumn{5}{|c|}{ Statements } \\
\cline { 2 - 6 } & $\begin{array}{c}\text { Testing for } \\
\text { radon is easy }\end{array}$ & $\begin{array}{c}\text { Testing the } \\
\text { house I live in } \\
\text { for radon is a } \\
\text { priority }\end{array}$ & $\begin{array}{c}\text { There is no use to } \\
\text { test the home } \\
\text { I live in for radon. } \\
\text { I always maintain } \\
\text { good ventilation }\end{array}$ & $\begin{array}{c}\text { could not afford to } \\
\text { take measures to } \\
\text { reduce the radon } \\
\text { level in the house } \\
\text { I live, in five years } \\
\text { time }\end{array}$ & $\begin{array}{c}\text { The decision to } \\
\text { take actions to } \\
\text { reduce the radon } \\
\text { level in the house } \\
\text { I live is not en- } \\
\text { tirely up to me }\end{array}$ \\
\hline Strongly disagree & 8.3 & 7.3 & 3.3 & 3.5 & 2.5 \\
\hline Disagree & 24.7 & 22.6 & 19.1 & 15.8 & 11.6 \\
\hline Neither agree nor disagree & 24.7 & 27.4 & 31.3 & 22.4 & 10.1 \\
\hline Agree & 11.0 & 21.4 & 29.2 & 27.7 & 54.7 \\
\hline Strongly agree & 2.1 & 2.7 & 4.2 & 7.5 & 14.1 \\
\hline I don't know & 28.3 & 16.5 & 12.1 & 21.6 & 5.7 \\
\hline I would prefer not to answer & 0.9 & 2.2 & 0.9 & 1.5 & 1.2 \\
\hline
\end{tabular}


Respondents' agreement with the statements about the need to measure radon concentration in a house with good ventilation, \%

\begin{tabular}{|l|c|c|}
\hline \multirow{2}{*}{\multicolumn{1}{|c|}{ Answer options }} & \multicolumn{2}{c|}{ Statements } \\
\cline { 2 - 3 } & $\begin{array}{c}\text { There is no use to test the home I live in for } \\
\text { radon. I always maintain good ventilation }\end{array}$ & $\begin{array}{c}\text { Regardless of the weather, I make sure that } \\
\text { my home is well ventilated }\end{array}$ \\
\hline Strongly disagree & 3.3 & 0.7 \\
\hline Disagree & 19.1 & 3.3 \\
\hline Neither agree nor disagree & 31.3 & 10.5 \\
\hline Agree & 29.2 & 57.3 \\
\hline Strongly agree & 4.2 & 26.9 \\
\hline I don't know & 12.1 & 0.7 \\
\hline I would prefer not to answer & 0.9 & 0.6 \\
\hline
\end{tabular}

Table 7

Respondents' potential willingness to take actions to reduce radon levels in their homes, $\%$

\begin{tabular}{|l|c|c|}
\hline \multirow{2}{*}{\multicolumn{1}{|c|}{ Answer options }} & \multicolumn{2}{|c|}{ Statements } \\
\cline { 2 - 3 } & $\begin{array}{c}\text { I would take immediate actions to reduce } \\
\text { the radon levels in the house I live }\end{array}$ & $\begin{array}{c}\text { It would be a priority over other risks to } \\
\text { take actions to reduce the radon level in the } \\
\text { house I live }\end{array}$ \\
\hline Strongly disagree & 0.9 & 1.7 \\
\hline Disagree & 1.7 & 5.8 \\
\hline Neither agree nor disagree & 9.3 & 22.3 \\
\hline Agree & 58.4 & 50.9 \\
\hline Strongly agree & 24.8 & 11.9 \\
\hline I don't know & 4.1 & 6.5 \\
\hline I would prefer not to answer & 0.8 & 0.9 \\
\hline
\end{tabular}

To determine the proportion of respondents who were convinced that radon was dangerous and the need to take protective measures in the absence of the above obstacles (Table 5), some questions about the potential readiness to take measures to reduce the radon levels in homes were asked (Table 7).

$83.2 \%$ of respondents claimed that they would take immediate actions, and it would be a priority over other risks to take such actions for $62.8 \%$ of respondents. When analyzing these distributions, it is necessary to keep in mind the "illusion of focus" and the principle of WYSIATI ("What You See Is All There Is") which says that the issue being discussed or more relevant issue at a particular moment becomes more important in comparison with others [25].

Since the survey focuses specifically on radon, some respondents are more likely to assess the radon issue as significant and requiring action. However, we cannot be sure that in the future respondents will use their limited resources specifically to measure and / or reduce radon levels in their homes if other issues emerge.

A person answering questions about his or her life does not go into a detailed analysis and is prone to momentary mood. However, it can be noted at least that information on radon received from Rospotrebnadzor (Federal Service for Surveillance on Consumer Rights Protection and Human Wellbeing) and its scientific research institute forms attitudes towards the perception of radon as a risk factor for the majority of respondents requiring actions to mitigate its impact on health.

Among those who take their health seriously (Table 3 ), the proportion of those who are willing to take immediate actions to reduce radon level in their homes is higher $(89.1 \%$ vs. $81.8 \%$ among the rest). This category also includes a higher proportion of those who say that taking actions to reduce radon levels in their homes would be a priority $(74.8 \%$ vs. $60.4 \%$ among the rest). 
Another significant factor influencing the willingness to take measures and give them higher priority is the trust in experts. For example, among those willing to delegate decisions on their health to experts, $87.0 \%$ would immediately take radon protective measures (vs. $80.1 \%$ among the rest) and for $67.8 \%$ they would be a priority (vs. $58.7 \%$ among the rest).

The statements presented in Table 8 also test the comprehension and persuasiveness of information on radon which was given earlier. After reading the box with some key information on radon, $83.0 \%$ of respondents agreed with the statement that radon was a radioactive gas. To compare significance of risk of indoor exposure to radon compared to other risks turned out to be a difficult task for the respondents, thus most estimates were in the middle of the scale: "disagree" (25.8\%), "neither agree nor disagree" (26.1\%), "agree" (19.0\%). The reason for this lies in the fact that respon- dents were not provided with information on other risks due to the limitations, goals and objectives of the survey. Meanwhile, it is known that without reference points for comparison, it is difficult for a person to make a judgment [26]. This fact should be taken into account while communicating radon risk. Some experts emphasize that the population needs both practical guides to action and theoretical information [23, 27].

The question about radon as the cause of diseases revealed the potential for the emergence of myths about radon in the case of unwary and unprepared risk communication. $79.3 \%$ of the respondents correctly claimed that radon could be the cause of lung cancer (Table 9). At the same time, despite the information provided, some respondents indicated that radon could also cause other diseases (50.6\% for asthma, $38.3 \%$ for allergies, $35.2 \%$ for skin diseases, and $48.4 \%$ for other respiratory diseases).

Table 8

Respondents' agreement with statements testing the comprehension of information on radon, \%

\begin{tabular}{|l|c|c|}
\hline \multirow{2}{*}{\multicolumn{1}{c|}{ Answer options }} & \multicolumn{2}{|c|}{ Statements } \\
\cline { 2 - 3 } & Radon is a radioactive gas & $\begin{array}{c}\text { Compared to other risks, exposure to } \\
\text { indoor radon does not pose a significant } \\
\text { risk for my health }\end{array}$ \\
\hline Strongly disagree & 1.1 & 7.9 \\
\hline Disagree & 2.6 & 25.8 \\
\hline Neither agree nor disagree & 6.3 & 26.1 \\
\hline Agree & 59.6 & 19.0 \\
\hline Strongly agree & 23.4 & 3.3 \\
\hline I don't know & 6.3 & 17.1 \\
\hline I would prefer not to answer & 0.8 & 0.8 \\
\hline
\end{tabular}

Table 9

Respondents' agreement with the statement "Radon exposure in high concentrations increases the risk of developing the following diseases", \%

\begin{tabular}{|c|c|c|c|c|}
\hline \multirow[b]{2}{*}{ Disease } & \multicolumn{4}{|c|}{ Answer options } \\
\hline & $\begin{array}{c}\text { Strongly } \\
\text { disagree or disagree }\end{array}$ & $\begin{array}{c}\text { Neither agree } \\
\text { nor disagree }\end{array}$ & $\begin{array}{c}\text { Strongly } \\
\text { agree or agree }\end{array}$ & $\begin{array}{c}\text { I don't } \\
\text { know or I would } \\
\text { prefer } \\
\text { not to answer }\end{array}$ \\
\hline Asthma & 8.2 & 18.7 & 50.6 & 22.6 \\
\hline Allergies & 13.0 & 24.9 & 38.3 & 23.7 \\
\hline Lung cancer & 2.3 & 7.0 & 79.3 & 11.4 \\
\hline Skin diseases & 11.7 & 27.9 & 35.2 & 25.0 \\
\hline Other types of cancers & 4.1 & 19.7 & 52.7 & 23.5 \\
\hline Other respiratory conditions & 7.4 & 20.4 & 48.4 & 23.8 \\
\hline
\end{tabular}



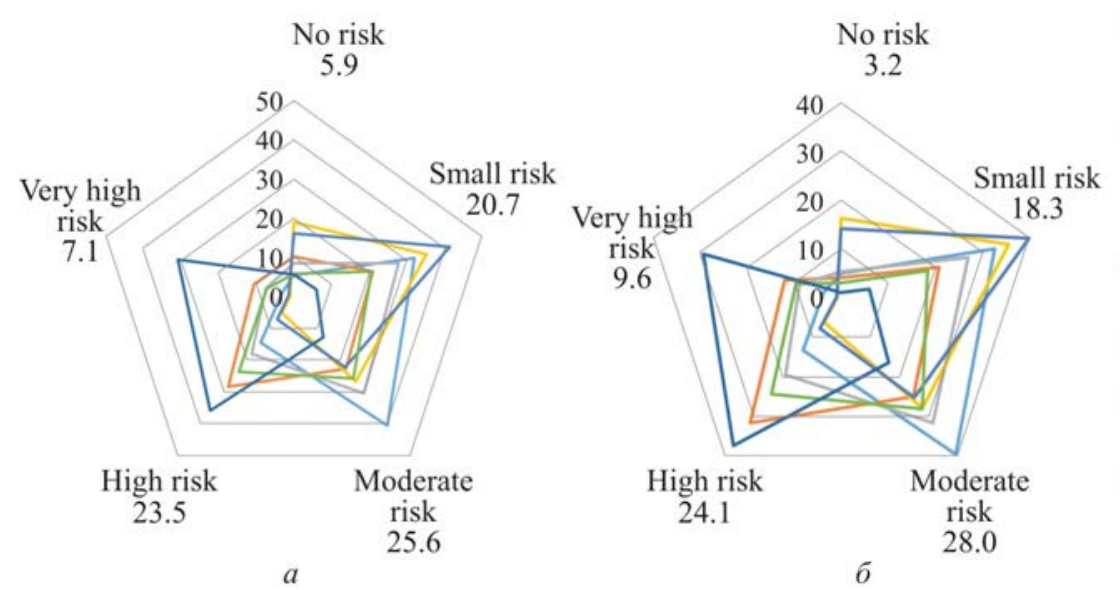

- Diagnostic medical exposure (eg x-rays, Cts, etc.)

- Nuclear power plant/reactor

Natural radioactivity in food
and drinking water

- A two-hour plane trip

- Security portals

- Radon in home/workplace

— Areas with high natural radioactivity (eg in the vicinity of a

Figure 1. Comparison of respondents' perception of radon as a risk with other radiation risks: a) for themselves personally, and b) for Russians in general, $\%{ }^{2}$

The published results of risk perception studies revealed a difference in the perception of personal and societal risks [28]. For example, the results of studies in the USA among those in whose homes radon measurements have already been carried out suggest that people tend to underestimate, rather than overestimate, the issue of radon in relation to their home [27].

No differences between the perception of radon at the personal and societal levels were found in our survey. This may be due to insufficient information provided to the respondents; this issue requires further research.

Figure 1 presents comparative data on the perception of radon among other radiation risks at the personal and societal levels. Given the "illusion of focus", the issue of radon is perceived by respondents after receiving key information as the third most dangerous among other radiation risks, for example, after areas with high natural radioactivity and nuclear power plants. It should be noted that for a half of the respondents $(52.2 \%$ in personal risk, $49.5 \%$ in societal risk) the risk from radon is "moderate", "low" or "absent", and only for one-third of the respondents $(30.6 \%$ in personal risk, $33.7 \%$ in societal risk) it is "high" or "very high".

Figures 2 and 3 show a comparison of respondents' use of various sources of informa- tion and trust in them. The most popular sources of information are the Internet, social media, and television (Figure 2). Medical specialists turned out to be the most trustworthy source of information on health risks, first of all, family doctors and physicians in polyclinics; people also trusted medical prevention centers, Rospotrebnadzor, regional and local public health care authorities (Figure 3).

Conclusions. According to the Requirement 50 of the IAEA General Safety Requirements Part 3, "The government shall provide information on levels of radon indoors and the associated health risks and, if appropriate, shall establish and implement an action plan for controlling public exposure due to radon indoors". At the same time, the strategy of communication with stakeholders, including the population, is considered as an integral part of the action plan (national radon program) [1]. Despite the fact that since the end of the Federal Target Program "Ensuring Nuclear and Radiation Safety for 2008 and for the period up to 2015", no radon-related activities have been carried out at the federal level in the Russian Federation, a possibility of establishing a national radon program in the future cannot be ruled out. In the Decree of the President of the Russian Federation No. 585 dated October 13, 2018 "On approval of the Fundamentals of State Policy in the field of ensuring

\footnotetext{
${ }^{2}$ The answer options "Do not know" and "I prefer not to answer" are not presented, so the sum does not reach $100 \%$
} 


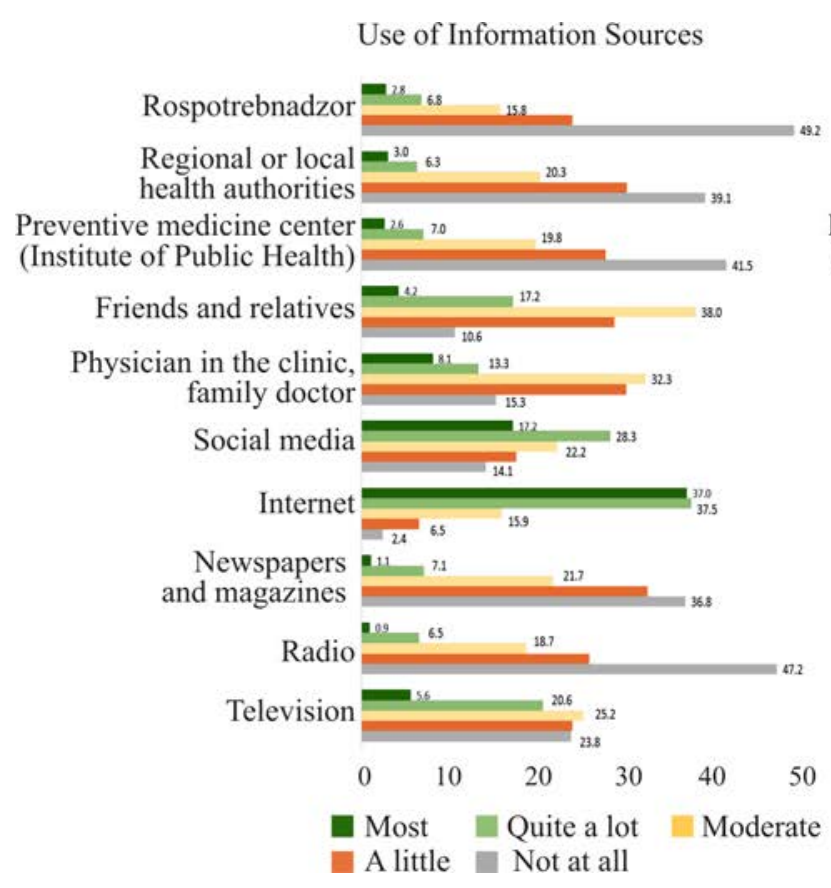

Figure 2. Respondents' use of various sources of information

nuclear and radiation safety of the Russian Federation for the period up to 2025 and beyond", one of the main areas of work is designated as "improvement of state control (supervision) over the impact on human health of natural sources of ionizing radiation, including radon and its progeny, in dwellings, children's institutions, public and industrial buildings". In this regard, the results of the present survey, which was the first social survey focused on the problem of radon and conducted nationwide, can be used as a basis for planning communication strategies within both national and regional radon programs.

Since a very low level of knowledge about radon was revealed among the respondents, it becomes obvious that there is an urgent need to raise public awareness of this problem through a planned information campaign, especially for the population in radonprone areas. The purpose of such a campaign may be, among other things, to refute existing myths about radon and prevent the appearance of new ones. It is extremely important to change the perception of the risk factor itself so that radon turns from a "natural radioactive gas" into a "harmful substance in the indoor air" for the population. This may prevent the

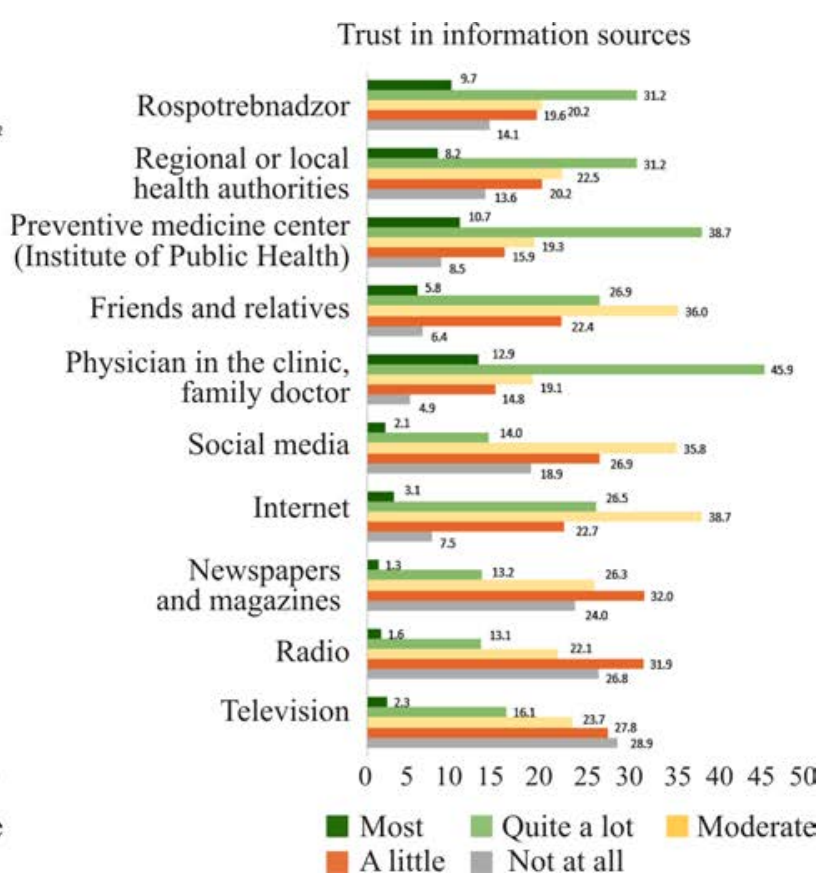

Figure 3. Respondents' trust in various sources of information

appearance of an attitude that a person is unable to control and influence this risk factor, so it is useless to take any protective action. As part of the information campaign, the population should be informed of the diseases that radon can cause and cannot cause. It's very important to inform people that in everyday life radon is a much more potentially dangerous source of exposure than other sources of ionizing radiation, but at the same time it is possible to take protective actions against it or to find out after taking measurements that this risk factor is irrelevant for a particular dwelling. It should be emphasized that measuring the indoor radon concentration is the only reliable way to identify the presence or absence of this risk factor, but at the same time, measurements are not a significantly financial and time-consuming procedure.

The results of health risk assessment such as the annual number of radon-induced lung cancer deaths that could be prevented if the indoor radon concentrations in many dwellings became much lower [5, 29], may be used as an additional argument in favor of radon protective and mitigation actions. Respondents in the survey noted that the main obstacle to the implementation of protective measures is the fact 
that the decision to take actions to reduce the radon level in the house is not entirely up to them. In this situation, risk communications can involve not only the residents of apartment buildings, but also the management companies or homeowners' associations in order to convince them and the residents of the houses they manage of the need for measurements and, if necessary, radon protective or mitigation actions. In this case, we can suggest using such means of risk communications as development of brochures, manuals and other guidance documents, informational and training videos, publications and interviews of experts in local media, including social media.

The results of the survey show that the population (note that the sample consisted of Internet users) prefers to get information on health risk factors from the Web, while representatives of the public healthcare authorities and supervisory agencies appear to be the most trustworthy. For this reason, it seems appropriate to use the interest of Russians in general and journalists in particular in health issues and the increased credibility of Rospotrebnadzor during the COVID-19 pandemic to conduct information campaigns to increase the public perception of such a risk factor as radon. Moreover, it seems logical to integrate radon issues into other health-related campaigns, for example, aimed at protecting human health from the effects of secondhand smoke and direct tobacco smoking or at reducing the mortality from malignant neoplasms through, among other things, early and mass diagnostics. In this case, we can suggest using the accounts of Rospotrebnadzor and health care authorities in various social media, where information is most often presented not only in text form, but also in graphic or audiovisual, which is much easier to perceive, as well as organizing interviews of experts on television, radio and in online media. It should be noted that companies on the market of services related to radon measurements, as well as the development and implementation of radon protective and mitigation measures, should in this case be ready for a potential increase in the number of applications from interested citizens and organizations.

This highlights the main feature of the development and implementation of radon programs: they can be successfully implemented only in case there is close and coordinated interaction between a large number of stakeholders. Their work should be based on the desire to improve the quality of life of citizens of the country, preserve their health and increase life expectancy.

Funding. The research was not granted any financial support.

Conflict of interests. The authors declare there is no conflict of interests.

\section{References}

1. WHO handbook on indoor radon: a public health perspective. Geneva, WHO Press Publ., 2009, $110 \mathrm{p}$.

2. Radiologicheskaya zashchita ot oblucheniya radonom [Radiological protection against radon exposure]. In: M.V. Zhukovskii, I.V. Yarmoshenko, S.M. Kiselev eds. Moscow, ICRP Publ., 2015, 92 p. (in Russian).

3. Protection of the public against exposure indoors due to radon and other natural sources of radiation. IAEA Safety Standards Series No. SSG-32. Vienna, International Atomic Energy Agency Publ., 2015, 90 p.

4. Radon: ot fundamental'nykh issledovanii k praktike regulirovaniya [Radon. From basic research to regulatory practice]. In: S.M. Kiselev, M.V. Zhukovskii, I.P. Stamat, I.V. Yarmoshenko eds. Moscow, FGBU GNTs FMBTs im. A.I. Burnazyana FMBA Rossii Publ., 2016, 432 p. (in Russian).

5. Romanovich I.K., Stamat I.P., Kormanovskaya T.A., Kononenko D.V. Prirodnye istochniki ioniziruyushchego izlucheniya: dozy oblucheniya, radiatsionnye riski, profilakticheskie meropriyatiya [Natural sources of ionizing radiation: radiation doses, radiation risks, preventive measures]. In: G.G. Onishchenko, A.Yu. Popova eds. Saint Petersburg, FBUN NIIRG im. P.V. Ramzaeva Publ., 2018, 432 p. (in Russian). 
6. Barkovsky A.N., Akhmatdinov R.R., Akhmatdinov R.R., Biblin A.M., Bratilova A.A., Zhuravleva V.E., Kormanovskaya T.A., Kuvshinnikov S.I. [et al.]. The outcomes of functioning of the unified system of individual dose control of the Russian federation citizens based on the 2019 data. Radiatsionnaya gigiena, 2020, vol. 13, no. 4, pp. 110-119 (in Russian).

7. Tirmarche M., Harrison J.D., Laurier D., Paquet F., Blanchardon E., Marsh J.W. [et al.]. ICRP Publication 115. Lung cancer risk from radon and progeny and statement on radon. Ann. ICRP, 2010, vol. 40, no. 1, pp. 1-64. DOI: 10.1016/j.icrp.2011.08.011

8. Sources, Effects and Risks of Ionizing Radiation. UNSCEAR 2019 Report to the General Assembly, with Scientific Annexes. New York, United Nations Publ., 2020, 301 p.

9. Makedonska G., Djounova J., Ivanova K. Radon risk communication in Bulgaria. Radiation Protection Dosimetry, 2018, vol. 181, no. 1, pp. 26-29. DOI: 10.1093/rpd/ncy096

10. Lofstedt R. The communication of radon risk in Sweden: where are we and where are we going? Journal of Risk Research, 2019, vol. 22, no. 6. pp. 773-781. DOI: 10.1080/13669877.2018.1473467

11. Cronin C., Trush M., Bellamy W., Russell J., Locke P. An examination of radon awareness, risk communication, and radon risk reduction in a Hispanic community. International Journal of Radiation Biology, 2020, vol. 96, no. 6, pp. 803-813. DOI: 10.1080/09553002.2020.1730013

12. Khan S.M., Krewski D., Gomes J., Deonandan R. Radon, an invisible killer in Canadian homes: perceptions of Ottawa-Gatineau residents. Canadian Journal of Public Health, 2019, vol. 110, no. 2, pp. 139-148. DOI: $10.17269 / \mathrm{s} 41997-018-0151-5$

13. Coreţchi L., Overcenco A. European Council and international recommendations on radon exposure risk control. Arta Medica, 2020, vol. 77, no. 4, pp. 103-106. DOI: 10.5281/zenodo.4175168

14. Perko T., Turcanu C. Is internet a missed opportunity? Evaluating radon websites from a stakeholder engagement perspective. Journal of Environmental Radioactivity, 2020, no. 212, pp. 106-123. DOI: $10.1016 /$ j.jenvrad.2019.106123

15. Bouder F., Perko T., Lofstedt R., Renn O., Rossmann C., Hevey D., Siegrist M., Ringer W. [et al.]. The Potsdam radon communication manifesto. Journal of Risk Research, 2019, no. 26, pp. 1-4. DOI: $10.1080 / 13669877.2019 .1691858$

16. Hevey D. Radon risk and remediation: A psychological perspective. Frontiers in Public Health, 2017, vol. 27, no. 5, pp. 63. DOI: 10.3389/fpubh.2017.00063

17. Marennyy A.M., Kiselev S.M. The national radon program: Implementation experience and challenges for the future. Radiatsionnaya gigiena, 2019, vol. 12, no. 2, pp. 97-108. DOI: 10.21514/1998426X-2019-12-2s-97-108 (in Russian).

18. Biblin A.M. Development of the model of radiation risk-communication with the public for the arrangement of the research. Radiatsionnaya gigiena, 2019, vol. 12, no. 1, pp. 74-84. DOI: 10.21514/1998-426X-2019-12-1-74-84 (in Russian).

19. Burd'e P. Sotsiologiya politiki. Obshchestvennoe mnenie ne sushchestvuet [Sociology of politics. Public opinion does not exist]. Sotsiologicheskoe prostranstvo P'era Burd'e. Available at: http://bourdieu.name/content/obshhestvennoe-mnenie-ne-sushhestvuet (20.08.2020) (in Russian).

20. Champagne P. Making an opinion: a new political game. Polis. Politicheskie issledovaniya, 1992, no. 3, pp. 177-180 (in Russian).

21. Yudin G.B. Oprosy obshchestvennogo mneniya [Public opinion polls]. Puti Rossii. Voina i mir: sbornik statei, Saint Petersburg, Nestor-Istoriya Publ., 2017, pp. 63-73 (in Russian).

22. Davydov A.A., Kononenko D.V., Biblin A.M. Study of public opinion on the unknown risk factor: international comparative study of radon risk perception. Sotsiologiya i obshchestvo: traditsii $i$ innovatsii $v$ sotsial'nom razvitii regionov: sbornik dokladov VI Vserossiiskogo sotsiologicheskogo kongressa. Moscow, ROS, FNISTs RAN Publ., 2020, pp. 1499-1506 (in Russian).

23. Davydov A.A., Biblin A.M., Kononenko D.V., Vasil'eva O.S., Khalova P.M. Organizatsiya vserossiiskogo sotsial'nogo oprosa po radonu [Organization of an all-Russian social survey on radon]. Sovremennye problemy epidemiologii, mikrobiologii i gigieny: materialy XII Vserossiiskoi nauchnoprakticheskoi konferentsii molodykh uchenykh i spetsialistov Rospotrebnadzora. In: A.Yu. Popova, A.K. Noskov eds. Rostov-na-Donu, OOO «MiniTaip» Publ., 2020, pp. 146-148.

24. Weinstein N.D., Lyon J.E., Sandman P.M., Cuite C.L. Experimental evidence for stages of health behavior change: the precaution adoption process model applied to home radon testing. Health Psychology, 1998, vol. 17, no. 5, pp. 445-453. DOI: 10.1037/0278-6133.17.5.445 
25. Weinstein N.D., Sandman P.M. A model of the precaution adoption process: evidence from home radon testing. Health Psychology, 1992, vol. 11, no. 3, pp. 170-180. DOI: 10.1037/0278-6133.11.3.170

26. Kruger J., Dunning D. Unskilled and unaware of it: how difficulties in recognizing one's own incompetence lead to inflated self-assessments. Journal of personality and social psychology, 1999, vol. 77, no. 6, pp. 1121-1134. DOI: 10.1037//0022-3514.77.6.1121

27. Kahneman D. Thinking, Fast and Slow. New York, Farrar, Straus and Giroux Publ., 2013, 499 p.

28. Keller C., Siegrist M., Visschers V. Effect of risk ladder format on risk perception in high- and low-numerate individuals. Risk Analysis: An International Journal, 2009, vol. 29, no. 9, pp. 1255-1264. DOI: $10.1111 / \mathrm{j} .1539-6924.2009 .01261 . x$

29. Weinstein N.D., Klotz M.L., Sandman P.M. Promoting remedial response to the risk of radon: Are information campaigns enough? Science, Technology, \& Human Values, 1989, vol. 14, no. 4, pp. 360-379. DOI: $10.1177 / 016224398901400403$

30. Sjöberg L. The different dynamics of personal and general risk. Risk Management, 2003, no. 5, pp. 19-34. DOI: 10.1057/palgrave.rm.8240154

31. Kononenko D.V., Kormanovskaya T.A. Risk assessment for the population of the regions of the Russian Federation from constant lifelong exposure to radon. Mediko-biologicheskie problemy zhiznedeyatel'nosti, 2019, no. 1 (21), pp. 56-61 (in Russian).

Davydov A.A., Biblin A.M., Kononenko D.V. Radon risk communication issues: results of the all-russian public opinion survey. Health Risk Analysis, 2021, no. 3, pp. 29-41. DOI: 10.21668/health.risk/2021.3.03.eng

Received: 08.04.2021

Accepted: 07.06.2021

Published: 30.09.2021 